Department of Archaeology and Museology

http://dx.doi.org/10.12775/AHP.2019.001

Masaryk University

Brno, Czech Republic

PETER MILO

\title{
Early Medieval hillforts and the possibilities of their investigation by geophysical methods ${ }^{1}$
}

\section{Możliwości wykorzystania metod geofizycznych w badaniach wczesnośredniowiecznych grodów}

Abstract. This contribution deals with research into early medieval hillforts by means of geophysical methods. Comparison of archaeological sources and results of geophysical measurements was used for the analysis of some previous and more recent results, while future possibilities of research are outlined as well. In geographical terms, the article focuses on the north regions of the Central Danubian Basin, particularly Moravia and western Slovakia. The research is aimed at integral sections of Great Moravia that was forming in this territory in the $9^{\text {th }}$ century, whereas the majority of local hillforts are connected with its existence. Archaeology of the neighbouring regions in the period of the early Middle Ages is in many respects similar to that of the Central Danubian Basin, and the general outcomes can thus be extended to the whole of Central Europe.

Keywords: hillforts, early medieval, geophysical methods, Moravia, Slovakia.

The history and state of geophysical survey of hillforts

Geophysical survey of Early Medieval hillforts has a long history. In Czechoslovak archaeology, the first geophysically investigated location of a fortification character was the Stará Kouřim hillfort. In 1950, the site was visited by prof. R. Běhounek and a group of students from the Prague Technical College who, using electrical resistivity methods, measured an ideal cross-section through the ditch of the central rampart of the hillfort (Šlle 1977, p. 95). One of the first systematic geophysical measurements at hillforts in Moravia was also research conducted in

1 This publication is based on research supported by the Czech Science Foundation (GA CR) under Grant No. 18-16153S. 
the late 1970s and the early 1980s by Vladimír Hašek, who would often work at the sites directly during archaeological excavations. These involved, for example, Uherské Hradišš - Staré Město (Hašek, Měřínský 1991, p. 94-96), the hillforts Spytihněv and Strachotín-Petrova louka (Hašek et al. 1983) and Břeclav-Pohansko (Dostál et al. 1981, p. 49-59). Further important investigations include prospection in the Chotěbuz-Podobora hillfort (Poláček et al. 1983). The more recent research of Moravian hillforts focused on large areas of fortified complexes, parts of fortifications, as well as selected areas outside the fortified settlements include geophysical surveys in Mikulčice and Břeclav-Pohansko (Křivánek 2005; Milo, Dresler, Macháček 2011).

The first geophysical measurements of early medieval hillforts in Slovakia were conducted in 1976. Magnetometric prospection was carried out in Pobedim (Ludikovský, Hašek, Obr 1978) and electrical resistivity tomography at the Ducové hillfort (Gajdoš 1978, p. 116). Research activity increased significantly in the early $21^{\text {st }}$ century when the hillforts Majcichov and Pobedim were geophysically surveyed (Ruttkay et al. 2006). These activities were soon expanded by research of large surrounding areas of hillforts such as Bíňa (Ruttkay et al. 2006), Bojná (Pieta et al. 2011) and Pružina (Kováčová, Kovár, Milo 2015). Character of fortifications, their destruction, the distribution and density of features inside the fortified areas and outside them were documented, what has expanded information about the hillforts significantly.

Numerous geophysical surveys of Early Medieval hillforts have been conducted in recent years by the Institute of Archaeology and Museology of the Masaryk University in Brno. Using multiple methods, the researchers investigated ten Early Medieval hillforts in Moravia and Slovakia (fig. 1). The main goal of these geophysical surveys was to document the structure of the inner built-up areas and to determine internal structure of the ramparts at selected hillforts. Another aim was to inspect the efficiency of the ground-penetrating radar (GPR), electrical resistivity tomography (ERT) and magnetometry on sites with Early Medieval fortifications.

For the purposes of the GPR survey, a single channel apparatus X3M Ramac (Geoscience Malå) with two shielded antennas with a central frequency of 500 and $250 \mathrm{MHz}$ was used. Where possible, we conducted a survey in a polygon area, where not, only single profiles were measured. The collected data were processed using the RAMAC Ground Vision software (Geoscience Malå). For the purposes of the ERT, we applied 2D ERT measurement, using three types of configuration: Wenner, Schlumberger and dipol-dipol with electrodes distance 0.5 or $1 \mathrm{~m}$. The used lengths of profiles were 36,47 and $73 \mathrm{~m}$, varying by site, with the objective to measure the whole rampart. The measurements were carried out by the ARES equipment (GF Instruments Brno) and the collected data were processed by the Res2Dinv software (Geomoto Inc.). The magnetic surveys were carried out by 


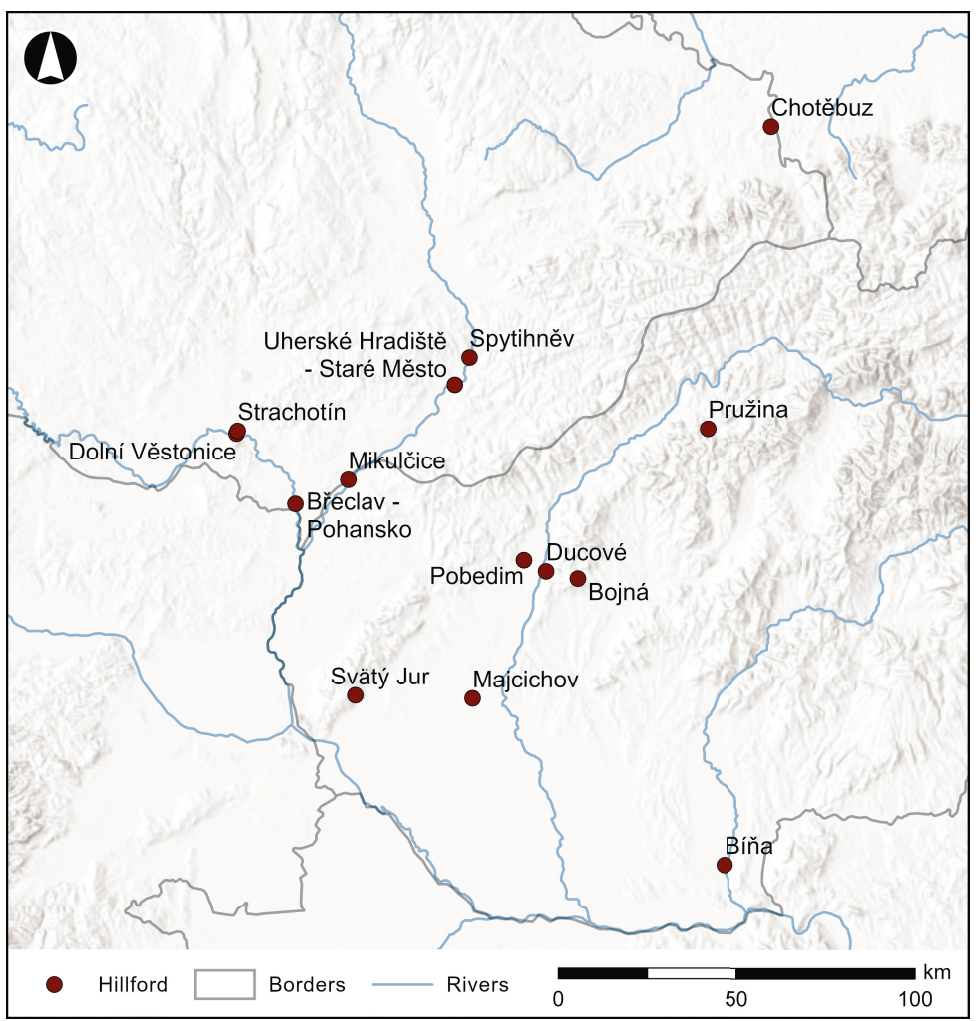

Fig. 1. Central Danubian Basin and hillforts investigated by geophysical methods and mentioned in the article (edited by P. Milo)

Ryc. 1. Grodziska na Nizinie Panońskiej badane metodami geofizycznymi ujęte w artykule (oprac. P. Milo)

the magnetometers Ferex (Förster) and LEA MAX (Eastern Atlas) with FEREX CON 650 probes using Surfer and LEAD2 softwares. Topographic information for each survey was gathered using RTK GPS or Total Station.

\section{Fortifications}

The basic building materials used for the construction of Early Medieval fortifications were earth and wood, in some cases supplemented with stone. Today, only rampart structures are found instead of these fortifications, often representing only secondary manifestations of the destructions of the original fortifications.

In the initial phase of the development of Early Medieval fortification techniques in the territory of the Central Danubian Basin, simple fortifications prevailed (Staňa 1972, p. 113-114; Procházka 2009, p. 255). The pre-Great Moravian period 
was characterized by loosely arranged posts with gaps between them, probably interlinked by wicker walls discovered, for example, in Mikulčice and Uherské Hradiště. Typical fortification elements of this period might have included simple wooden palisades (Procházka 2009, p. 255). In the mid-9 ${ }^{\text {th }}$ century, the importance of palisade fortifications started to decline and they were replaced with more complex fortification types. In the central area of Great Moravia, the most widespread construction types were the fortifications with stone front wall and a wooden back wall, investigated, for example, in Mikulčice, Břeclav-Pohansko, Majcichov and a number of other sites (Procházka 2009, p. 257). The width of Great Moravian fortifications ranged from 1 to $9 \mathrm{~m}$. The majority of fortifications with a stone wall were 4 to $6 \mathrm{~m}$ wide. The height of the fortifications was typically between 3.5 and $4.5 \mathrm{~m}$ (Procházka 2009, p. 263). The basic information about the forms of Medieval fortifications is important for geophysical fieldwork, when it is necessary to determine which forms of archaeological structures can be expected in geophysical data. The detailed study of individual forms of fortifications can thus enable a more accurate interpretation of geophysical measurements.

The main tasks of geophysical survey often involve detection of forms that are 'invisible' or hardly discernible in the terrain and which might indicate the presence of fortification elements such as ditches, ramparts or palisades. At locations where these elements can be detected, geophysical survey formulates or even directly answers questions regarding the determination of the forms, construction, bulkiness or depth of these elements. Important issues that can be revealed include the state of preservation of a fortification in its individual sections, as it plays a key role in planning of the archaeological fieldwork as well as in the heritage protection.

On the whole, it can be said that geophysical survey of hillforts had been, until 1980 s, mostly oriented on detection and location of fortification elements. The reason is simple. The measuring technology of that time could only exceptionally, and under extremely favourable geological, pedological and archaeological conditions and contexts, detect features of small dimensions such as settlement pits and sunken houses. Another reason is that the method predominantly employed in fieldwork was ERT, which is not exactly suitable for the detection of sunken features the infill of which does not differ much in its material from the surroundings. On the other hand, stone parts of fortifications and their destruction showed sufficiently large differences in material conductivity, manifested in contrasting and more easily interpreted anomalies.

Examples of the intense use of ERT include prospection at the ChoterbuzPodobora hillfort. The aim of the geophysical prospection was the identification and recording of construction elements of defensive ramparts in the acropolis and the first bailey, as well as the location of presumed settlement features in selected areas of the site (Poláček et al. 1983, p. 162). On the south edge of the acropolis, a system of profiles and ERT measurements were used to investigate the course 
of a rampart fortification. All profiles showed two resistivity maxima, separated by low values of resistivity. Archaeological probing showed that these maxima corresponded to stone-stabilizing benches - berms' - of different widths and depths, which were made of circular river pebbles of diameters $10-15 \mathrm{~cm}$, placed in a single layer. Both berms were supporting almost $9 \mathrm{~m}$ wide earthen bulk of the rampart (Poláček et al. 1983, p. 162, fig. 4, 5). One profile was investigated at the massive rampart section of the east bailey, using the ERT. A course of resistivity similar to previous profiles enabled to formulate a hypothesis that stone remains of a fortification were present on this site as well (Poláček et al. 1983, p. 162, fig. 4).

The latest geophysical surveys of hillfort fortifications have shown that the ideal solution is the combination of ERT and GPR. In spring 2019, both methods were employed in the research of ten Early Medieval fortifications. All surveys were carried out close to the area that had been archaeologically explored in the past. This fact was an important advantage which enabled comparison of the results from geophysical survey and the results from previous archaeological excavations.

The two case studies, from the hillforts Bíňa and Svätý Jur-Neštich, represent surveys from sites of two different characters. Bíña is located in a flat area of the lowlands. The fortification was built without the use of stone material. The GPR profiles show a relatively homogenous picture. The ERT survey shows that the rampart has higher values of electrical resistivity in the lower central part, with a layer of lower values above it (fig. 2). It is a result of construction phases when the lower central part of the bank was made of topsoil from the area of the ditch and covered with a fill of clay from the lower part of the ditch. The top part of the banks is made up of loose drained organic soil (Milo et al. 2019).

The hillfort of Svätý Jur-Neštich is located in a hilly area, and stone material from the immediate surroundings was to a great extent used for the construction of the fortification. Both results - from the ERT and GPR survey - show the inner structure of the rampart with the remnants of stone destruction and the original bottom of the filled outer ditch in front of the rampart (fig. 3). The results also show that the surveyed ditch reached down to the bedrock. The rampart is made of material of the upper sediment, the lower bedrock, and possibly some clay fill (Milo et al. 2019).

Similar results were recorded at further locations; they are currently being processed and will be published in separate comparative study. Generally speaking, the range of results achieved on individual ramparts is well beyond expectations. By combining individual methods, several structural elements have been identified in detail in several ramparts. With the methods of ERT and GPR we could observe the original levels of the terrain, the stone and clay cores of the ramparts, the extent of the destruction of the stone walls as well as the character and depth of outer ditches. 

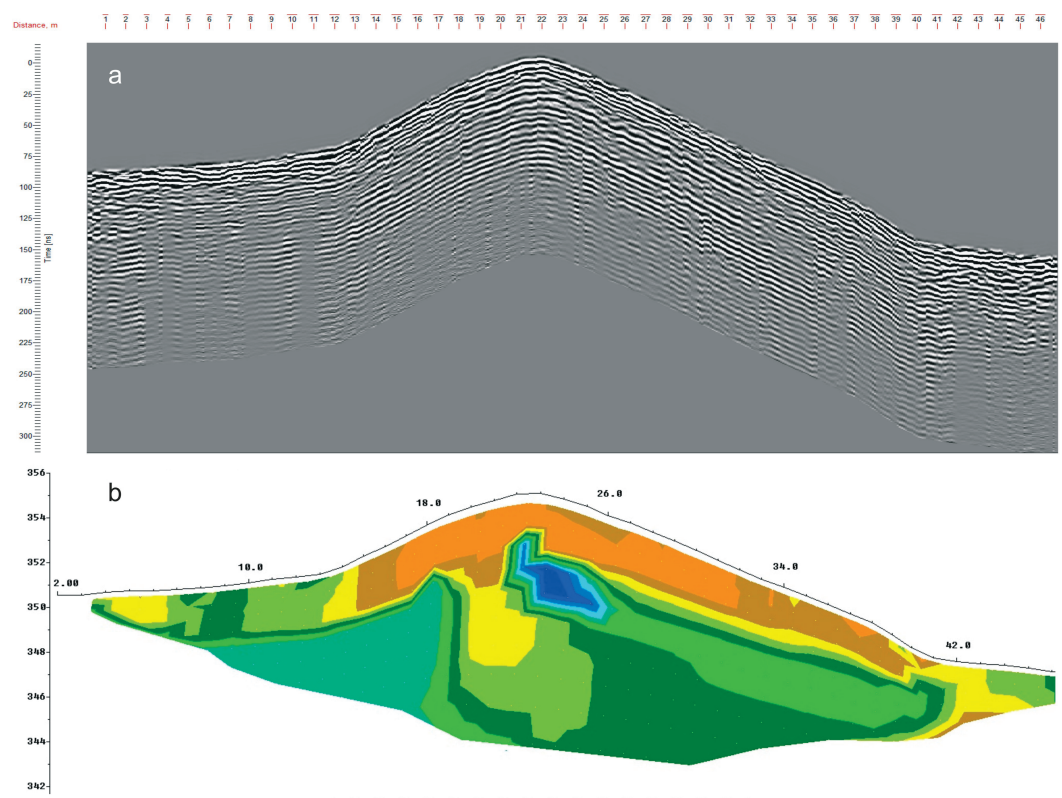

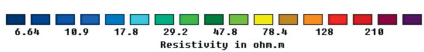

Fig. 2. Case study of GPR (a) and ERT (b) survey at the Early Medieval hillfort of Bíña, located in the south-western Slovakia. ERT profile with Wenner configuration. The results show that the rampart has higher values of electrical resistivity in the lower central part, covered by a layer of lower values above it (edited by P. Milo, I. Murín, M. Vágner)

Ryc. 2. Studium przypadku. Pomiary GPR (a) i ERT (b) na wczesnośredniowiecznym grodzisku Bíňa, położnym w południowo-zachodniej Słowacji. Profil ERT w wykonany w układzie Wennera. Wyniki wskazują, że konstrukcja wału ziemnego wykazuje wyższy opór w górnej i środkowej partii jest zaś pokryta warstwami o niższym oporze (oprac. P. Milo, I. Murín, M. Vágner)

In many cases, magnetometry has proved useful in detection of the fortification systems of Early Medieval hillforts. Under ideal conditions, magnetometry is also suitable for the detection of construction elements of fortifications. When original contexts are sufficiently preserved, it is even possible to identify the individual wooden and stone parts of fortifications. This particularly applies to cases when fortifications were burnt down.

Probably the most outstanding example of the detailed detection of a fortification by means of magnetometry was the prospection of the hillfort in Majcichov. The magnetogram shows the ditch, the rampart, and one interruption in the rampart interpreted as an entrance gate into the hillfort (Ruttkay et al. 2006). Considerable differences in magnetic values were recorded in the individual sections of the fortification. Its east, north and north-west sections were marked by high magnetic values. In contrast, the south and south-west sections of the rampart 


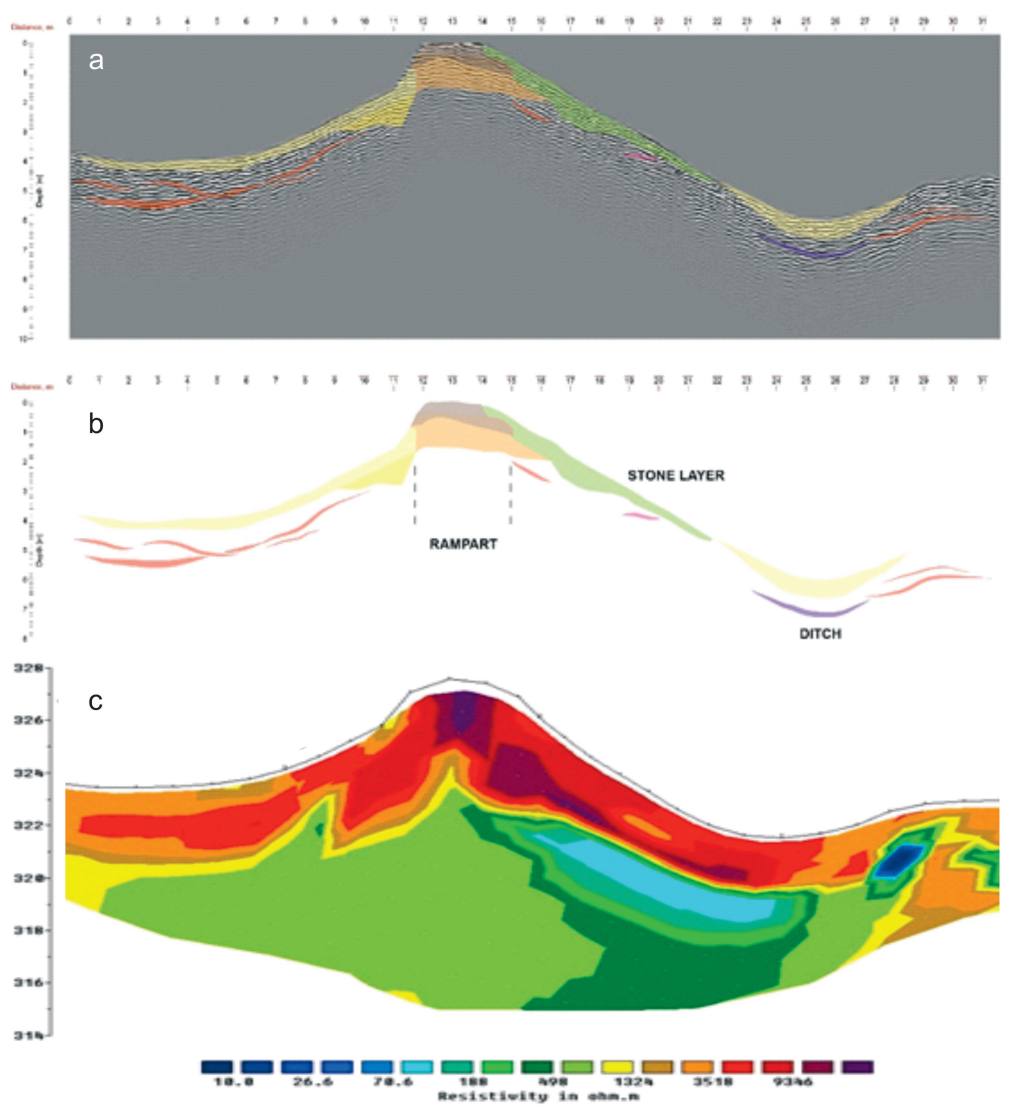

Fig. 3. Case study of GPR (a) and ERT (c) survey at the Early Medieval hillfort of Svätý Jur-Neštich, located in the south-western Slovakia. Results (b) show the inner structure of the rampart with the remnants of stone construction and the original bottom of the filled outer ditch in front of the rampart (edited by P. Milo, I. Murín, M. Vágner)

Ryc. 3. Studium przypadku. Pomiary GPR (a) i ERT (c) na wczesnośredniowiecznym grodzisku Svätý Jur-Neštich, położnym w południowo-zachodniej Słowacji. Wyniki (b) przedstwiają strukturę wałów, z pozostałościami konstrukcji kamiennych (płaszcza?) i pierwotnego dna fosy przy podstawie zewnętrznej umocnień (oprac. P. Milo, I. Murín, M. Vágner)

only manifested on the magnetogram as indications (fig. 4). The disproportion in the measured magnetic values was caused by the fire that had destroyed part of the fortification. The regularly alternating positive and negative magnetic values along the whole length of the rampart signalled its chamber-like structure (Henning, Milo 2005, p. 143-144, fig. 3, 6).

The following archaeological research confirmed the findings of the magnetic survey, and also expanded them in many respects. The front of the fortification 


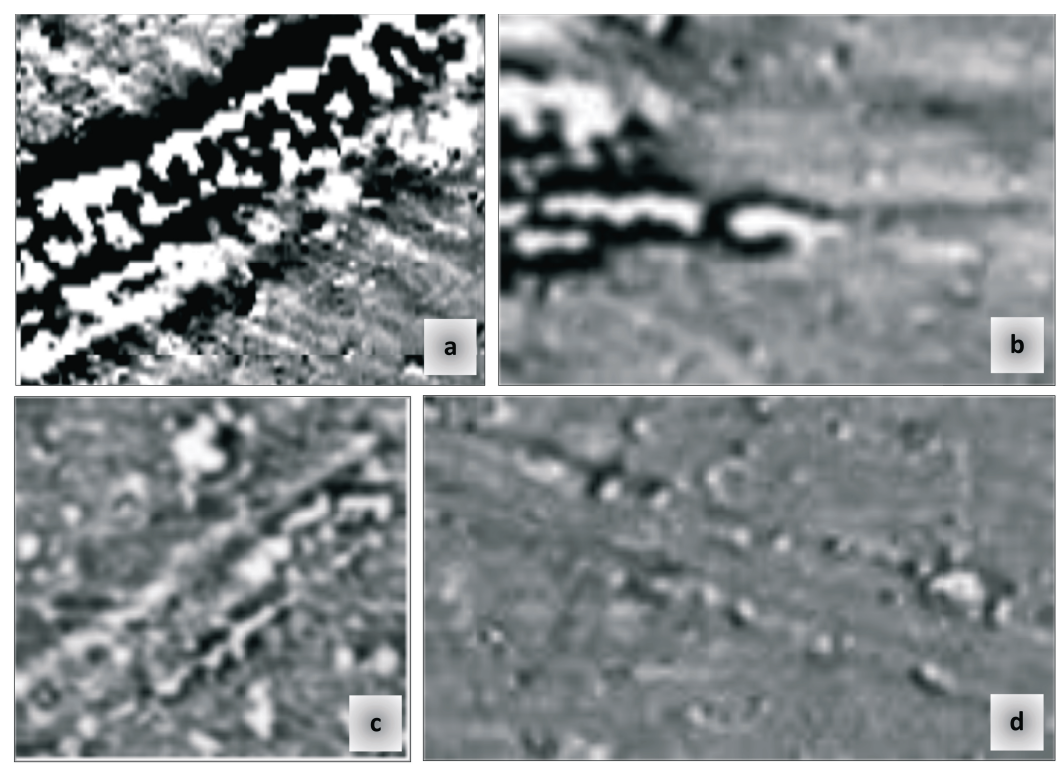

Fig. 4. a-Majcichov; section of the fortification exposed to intense heat; b-Majcichov; section of the fortification not exposed to fire; $\mathrm{c}$ - Pobedim; section of the fortification exposed to intense heat; $\mathrm{d}$ - Pobedim, section of the fortification not exposed to fire; magnetogram, dynamics of measured values $-3 /+3 \mathrm{nT}$ in 256 degrees of the grey scale (black/white), grid $0.25 \mathrm{~m} / 0.50 \mathrm{~m}$ (edited by P. Milo)

Fig. 4. a-Majcichov; fragment umocnień wystawiony na działanie wysokiej temperatury; b-Majcichov; fragment umocnień nie wystawiony na działanie ognia; c - Pobedim; fragment umocnień wystawiony na działanie wysokiej temperatury; d - Pobedim; fragment umocnień nie wystawiony na działanie ognia; magnetogram, odchylenia wartości pomiarowej-3/+3 nT w 256 stopniowej skali szarości, siatka $0.25 \mathrm{~m} / 0.50 \mathrm{~m}$ (oprac. P. Milo)

consisted of a stone wall made of loose stones. The chamber-like structure of the fortification partially rested on a wooden grate, partially on the bedrock. The frame probably consisted of hewn wooden beams. From the inside, the structure was reinforced by massive posts. The infill of the chambers was made of clay-like earth (Fottová, Henning, Ruttkay 2007, p. 222-225, fig. 6-9). On the map of the magnetic survey, the burnt chamber structure is manifested by high magnetic values, while the clay-like earth from the infill of the chambers and the remains of the stone wall have slightly lower magnetic values (fig. 4).

Contexts similar to Majcichov can be also observed at the hillfort in Pobedim. Archaeological excavations showed that the fortification had consisted of a wooden chamber-like structure filled with earth. The external wall was made up of loose stones. In front of the fortification, there was another defence element, a ditch (Bialeková 1998, p. 385-387). The preserved segments of the chamber-like structure 
of the fortification were also confirmed by magnetic survey. Even in this survey, the difference between the burnt and non-burnt sections of the fortification was clearly manifested (fig. 4). However, it should be noted that even in the non-burnt part of the hillfort a wooden chamber-like structure could be identified in several places. It is best visible in ca $30 \mathrm{~m}$ long segment of the fortification at the western part of the bailey. Geophysical data show a very weak negative anomaly which can be interpreted as a front and back walls and partitions separating individual wooden chambers. The fortification in this part was not burnt and the chamber-like structure and the earth placed around it were not remanently magnetized. This causes an effect opposite to that observed in the parts of the fortification exposed to fire. The wooden frame gradually rotted away. The earth material used for the construction of the rampart and for the infill of the chambers shows slightly higher magnetic values than the wooden elements of the fortification. Those can be observed in it as anomalies with lower magnetic values when compared to the surroundings (fig. 4).

Wooden sections of the fortification were also identified by magnetic prospection at the Břeclav-Pohansko hillfort (Milo, Dresler, Macháček 2011). During investigation of the southern segment of the fortification, distinct anomalies were detected, reaching values over $250 \mathrm{nT}$ (fig. 5). During surface prospection, a large amount of burnt daub was found. There were apparently traces of fire which destroyed the original wood-earth fortification in this section. There are also indications of a mighty wooden frame destroyed by intense heat. One of the interpretations suggests the existence of a wooden tunnel inside the fortification which was archeologically investigated in eastern section of the hillfort fortification in 2006 (fig. 5; Dresler, Milo, Šešulka 2007, p. 142-144; Dresler 2011, p. 104-106, fig. 117-121). Same situation was observed in northern part of the hillfort fortification. The rampart manifests four distinct magnetic anomalies, detected at regular intervals of 15 to 20 metres. It can be therefore presumed that these were regular wooden reinforcements of the tunnel system, similar to those excavated in eastern section of the hillfort fortification and geophysically detected in southern and eastern segments of the rampart. There will definitely be more situations like this in the whole fortification. Magnetic prospection proved highly effective for their detection. In the future, it will be possible to detect these parts of fortifications in advance, if the wooden parts of these tunnels had been exposed to a devastating fire. However, it should be noted that geophysical survey cannot always clearly identify individual fortification elements. Tunnel entrances detected at Pohansko were sometimes the only identified elements of the fortification, whereas large sections of the rampart did not manifest distinctly in geophysical data. 

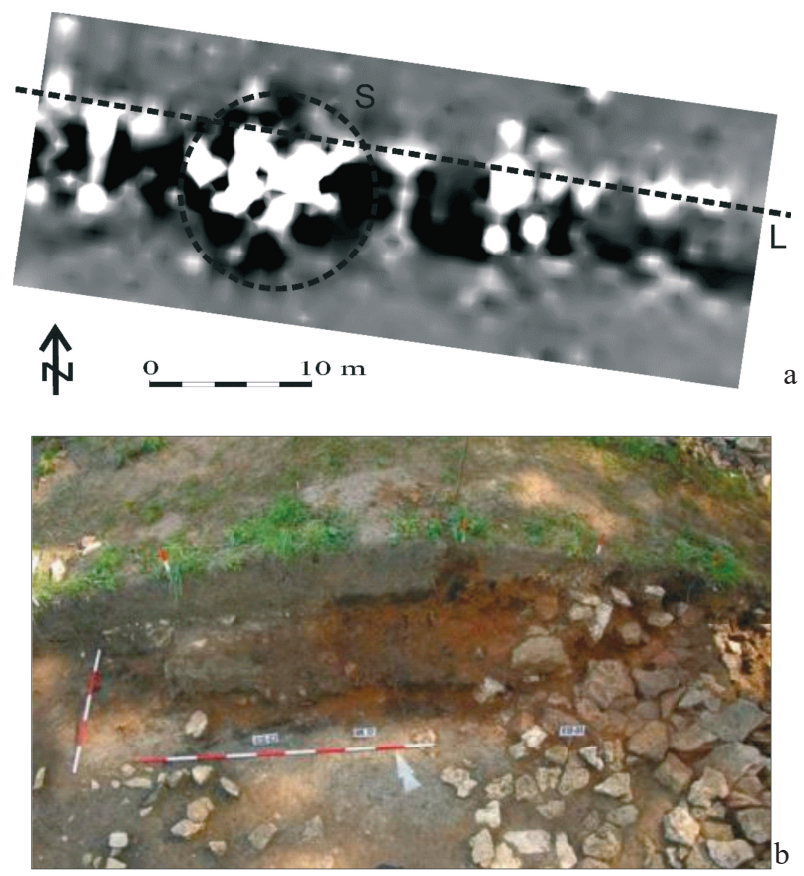

Fig. 5. Břeclav-Pohansko. a - southern segment of the rampart; magnetogram (L - line structure, remains of the inner wall of the fortification; $\mathrm{S}$ - distinct anomaly with values $>250 \mathrm{nT} / \mathrm{m}$ in the place of surface finds of burnt materials); $\mathrm{b}-$ archaeological research of the eastern segment of the rampart with a discovery of a burnt layer - remains of a wooden tunnel-shaped entrance to the fortification (after Dresler 2011, p. 228; edited by P. Milo)

Fig. 5. Břeclav-Pohansko. a-południowa partia wałów; magnetogram (L - struktura liniowa, pozostałość innego muru umocnień; S - znacząca anomalia o wartości $>250 \mathrm{nT} / \mathrm{m}$ w miejscu odnalezionych na powierzchni przepalonych materiałów); b - badania archeologiczne wschodniej partii wałów z odkrywką warstwy przepalonej - pozostałości drewnianej konstukcji bramy wjazdowej - tunelu w wałach (wg Dresler 2011, p. 228; oprac P. Milo)

\section{Structure of the built-up area and hillfort surrounding}

Standard archaeological methods are not suitable for detecting structure and character of house development of hillforts. Large-scale research in different parts of the sites would be necessary. Only two investigations of this kind have been applied to the central territory of Great Moravia: Mikulčice and Břeclav-Pohansko. Despite long-term investigations, the overall character of individual features and the intensity of habitation, as well as functional division of hillfort areas remain 
unclear at other sites. Geophysical, especially the large-scale magnetic survey is particularly helpful in these contexts.

Successful detection of archaeological structures at hillforts is based on the same principles as those applied to settlements, because identical settlement features might be expected. The main difference lies in the varying geological subsoil which might negatively affect research in a hilly environment where hillforts are often situated. Negative factors during research include a difficult terrain and often also dense forest vegetation.

This raises a question if and to what extent medieval structures of a settlement character, in our geographical region represented mostly by sunken features, can be recorded by geophysical prospection, and whether the value of information produced by geophysical measurements suffices to assess their character. Given that the presence of anomalies in the results of geophysical measurements does not automatically signal the presence of an archaeological feature, the identification of pattern structures plays an important role in interpretation of acquired data. For example, archaeological feature is defined only if a magnetic anomaly or anomalies create a recognizable and archeologically identifiable structure.

The most important construction elements of every settlement include residential features - houses. Typical Early Medieval dwellings in the investigated area were represented by sunken features of a square ground plan. The residential area of these sunken huts was approximately 10 to $15 \mathrm{~m}^{2}$. Although sunken huts appeared in this territory since Prehistory, their popularity increased significantly in the Iron Age. Most finds of sunken features come from the La Tène period, the Roman period and the Early Middle Ages. Sunken huts from the first two periods, however, were mostly rectangular, and in geophysical data can thus be easily distinguished from medieval sunken huts typical by square plans (Milo 2009, fig. 1).

A large proportion of features in Early Medieval hillforts comprised of various irregular and/or oval pits of a tub-like profile, with which we can only speculate to what above-ground features they had belonged to and what purpose they had served. It is generally presumed that they were parts of features with light above-ground structures or dwellings made of timber. They are often interpreted as remains of residential buildings. They are believed to have various functions; for example, they are interpreted as pits for heating or roasting, remains of production facilities, cellars, storage pits or sunken parts of animal sheds (Milo 2014, p. 26-154). It is obvious that these pits belonged to features of different character, from agricultural to residential buildings. Interpretation of anomalous features of irregular to oval ground plans is relatively problematic.

We are more certain about the features of round ground plans and structures with characteristically pear-shaped or sack-shaped profile, or prismatic pits that can be interpreted as storage pits. These grain silos represent typical features, especially in open settlements, but can also be found at hillforts. They are an 
evidence of the extent and types of farming activities at individual sites. The dimensions of the ground plans are typically 0.5 to $1 \mathrm{~m}^{2}$. Anomalies of this shape are relatively frequent in magnetic measurements. However, not all of them can be automatically determined as storage pits. The spectrum of the features manifesting in magnetic prospection by a round ground plan is large and includes settlement pits of different functions, large circular pits as well as hearths. Round ground plans might also occur with anomalies that signal features of small dimensions and of varied ground plans. This is connected with the density of geophysically measured points and the software data processing, during which the interpolation of data gives rise to rounded shapes in the results which do not necessarily mirror the shape of particular features. Interpretation of such structures is thus directly conditioned by verification in the form of archaeological excavations.

In recent years, research at large areas of several Early Medieval hillforts has been conducted. In the territory of Moravia and Slovakia, these include BřeclavPohansko, Dolní Věstonice-Vysoká zahrada, Ducové, Majcichov, Mikulčice, Pobedim, Pružina and Svätý Jur-Neštich. Břeclav-Pohansko and Mikulčice were definitely of central importance in Great Moravia. The importance of other sites is not yet clear, but, based on the current research, their importance seems to have been somewhat lower, probably being centres of regional importance.

The magnetic survey in Mikulčice identified numerous archaeological features located very close to each another and often overlapping. This can be considered evidence of multiple habitation phases, which fully corresponds to findings from archaeological research. The large density of habitation over a long chronological horizon does not allow to determine the structure of the habitation in individual periods. Information about the structure of occupancy can be only revealed by research into the sites settled less intensely or existing within a shorter period of time, otherwise the results would be limited to information about the settlement density and number of archaeological features. If settlement layer had been planned and organised, it can be detected by geophysical survey. Such sites include Břeclav-Pohansko. Pohansko is a lowland hillfort of approximately oval shape, with the area of ca 28 ha. In literature, Pohansko earned its recognition mainly thanks to the discovery of the 'Magnate's Court' (Kalousek 1971; Dostál 1975). The geophysically investigated area of the hillfort totalled over 12 ha. Numerous anomalies of different shapes and sizes were detected. On the basis of the orientation of individual anomalies and their comparison with the results of previous archaeological research, Jiří Macháček (2005, p. 122, fig. 13-18) reconstructed regularly structured habitation in the hillfort area, consisting of 'courts' of a perpendicular (square) ground plan and a network of streets. The sides of these courts were demarcated by different features and palisades. The inner area was usually empty. The courts had similar orientation and shape like the already 

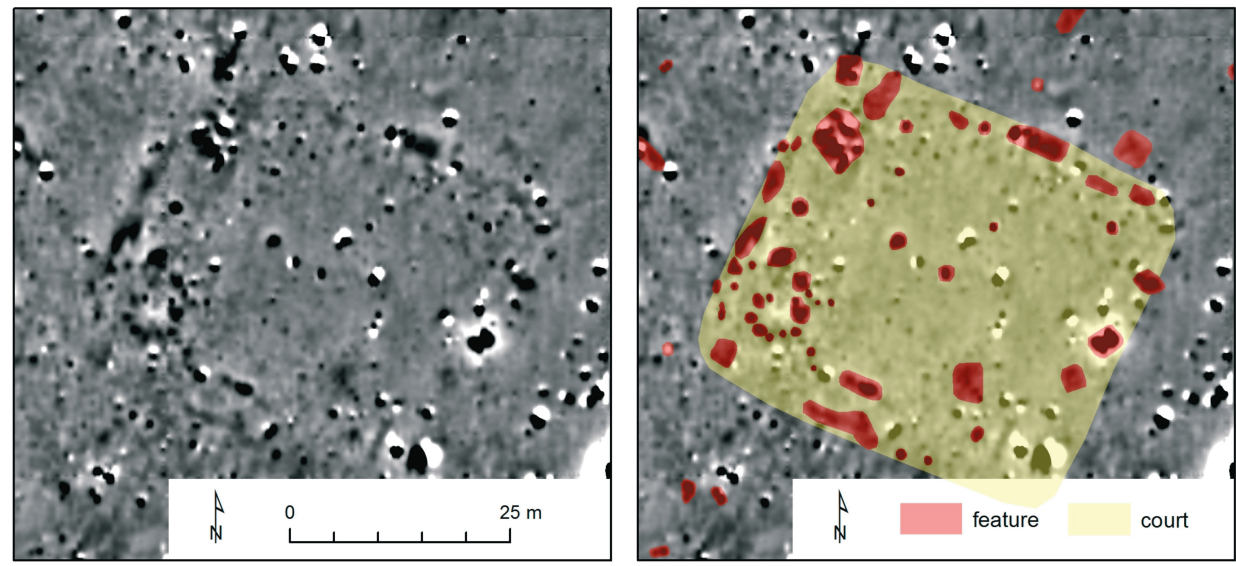

Fig. 6. Břeclav-Pohansko. Cross-section from a magnetogram, capturing anomalies which create a regular approximately square structure - a court. Left - magnetogram, dynamics of measured values $-3 /+3 \mathrm{nT}$ in 256 degrees of the grey scale (black/white), grid $0.25 \mathrm{~m} / 0.50 \mathrm{~m}$; right - interpretation (edited by P. Milo)

Fig. 6. Břeclav-Pohansko. Profil z magnetogramu wskazujący anomalie tworzące regularną (z grubsza prostokątną sturkturę - rynek. Po lewej-magnetogram, odchylenia wartości pomiarowej -3/+3 nT w 256 stopniowej skali odcieni szarości, siatka $0.25 \mathrm{~m} / 0.50 \mathrm{~m}$; po prawej - interpretacja wyników pomiarów (oprac. P. Milo)

mentioned Magnate's Court, yet their dimensions were smaller (a detailed image of one of them can be seen in figure 6).

Interesting findings came from the results of geophysical surveys at other hillforts. Pobedim and Majcichov are the only two Great Moravian hillforts completely investigated by geophysical methods in their whole area, including their closest hinterland. In Majcichov, only several potential features were discovered in the inner area of the hillfort. The reason is that a more recent flood layer was covering the original settlement horizon and hindered the identification of individual settlement features by magnetic survey (Ruttkay et al. 2006).

The hillfort in Pobedim covers the area of 8 ha and has two parts. A transverse inner fortification divides it into two sections, the main part on the Hradiště site and a bailey on the Podhradiště site. Archaeological research conducted by Darina Bialeková brought a large amount of interesting information and confirmed dense medieval and prehistoric settlements at the site (Bialeková 1978; 1996). Magnetic survey supplemented the information from archaeological research. Multiple magnetic anomalies suggest intense occupancy, especially at the Hradiště site (fig. 7). The features are scattered all over the area, and often make up clusters or groups. On the Podhradiště site, fewer archaeological features were detected. On the basis of their distribution it can be presumed that many of them are from the same period as the hillfort. Along the fortification separating the bailey from 
the main part, two parallel rows of archaeological structures can be observed, including an empty space between them. They are obviously oriented along the fortification line. These findings allow to describe the occupancy structure at least in this part of the hillfort. In all probability, on the basis of the results of magnetic measurements, it can be presumed that residential or other buildings were situated in rows located by along the road.

One of the main topics addressed by archaeology today include subsistence strategies closely linked to the immediate surroundings of the centres. The Pobedim hillfort is situated in the floodplain of the Váh River, now used for agriculture, in a landscape suitable for large-scale geophysical prospection. In spring 2019, an area of ca $1.2 \mathrm{~km}^{2}$ was surveyed there (fig. 7). The survey showed a dense network of small settlement units around the hillfort, indicating intense use of this area in the past. Dated archaeological material collected from surface prospection clearly manifests that the above-mentioned development of the settlement occurred mostly in the Early Middle Ages. Among other things, geophysical data show the course of former river tributaries and old routes. The series of finds supplements the discovery of a recently ploughed-up burial site. Without verification by archaeological

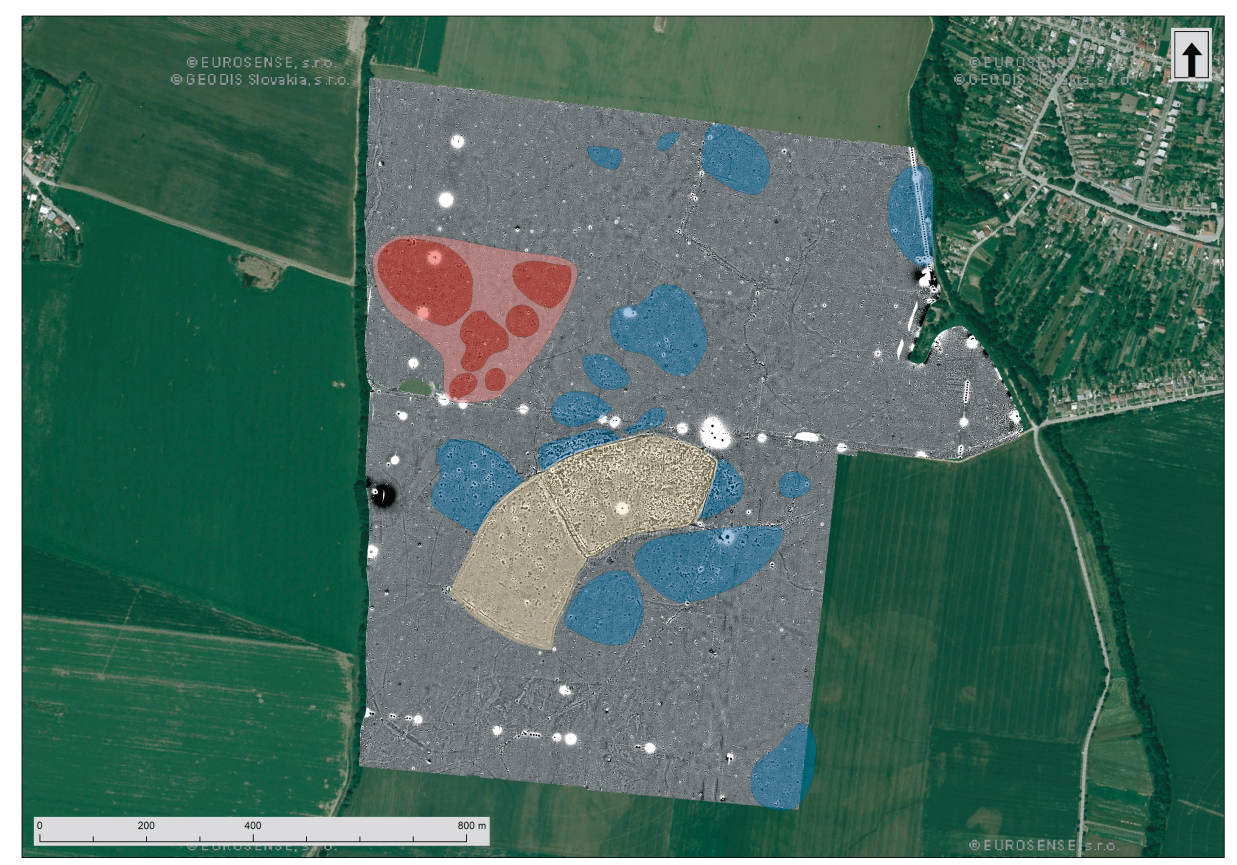

Fig. 7. Pobedim. Magnetogram of the hillfort and its hinterland; yellow - hillfort, blue - settlement, red - burial site (edited by P. Milo, T. Tencer)

Ryc. 7. Pobedim. Magnetogram grodziska z podgrodziem; żółty-grodzisko, niebieski- osada,czerwony - cmentarzysko (oprac. P. Milo, T. Tencer) 
research, however, we cannot be completely sure about the dating of the cemetery. However, based on related analogies (Bernhardsthal; Dresler et al. 2013), it can be presumed that it was an Early Medieval mound cemetery. The geophysical survey enables us to create a model layer showing the use of the landscape in the Early Middle Ages. Nevertheless, in the future, geophysical results will have to be verified by other natural science disciplines.

\section{Conclusion}

Examples of a large spectrum of surveys demonstrate the vast potential of the use of geophysics when it comes to research of Early Medieval hillforts. Geophysical prospection sheds an additional light on the history of the investigated sites and can be employed in further research, as well as in heritage care. By the proper combining of various geophysical methods we are able to, under suitable conditions, detect almost all kinds of features of archaeological research. Different types of magnetometres can locate sunken archaeological features (houses, storage pits and various settlement pits, ditches), as well as production features, traces of fire and construction elements of fortifications. Using the GPR we can detect stone structures such as buildings and stone parts of fortification systems and their destruction, as well as ditches and settlement features. ERT predominantly serve to address issues of fortification systems at individual sites.

However, it needs to be emphasized that geophysical survey cannot replace archaeological excavations, it can only supplement it. Geophysical surveys do not always bring accurate and clear information, and it is thus necessary to consider their limits. The result of every measurement is influenced by various external circumstances such as the mass, the type and homogeneousness of the soil horizon, the character of soil processes, geological conditions, segmentation of the geographical relief, water regime, level of groundwater, and the presence of more recent features on the sites. Individual geophysical methods might not give a full picture of the archaeological potential of an investigated area. Final decisions regarding the assessment of a site should never be made only on the basis of geophysics, and the results of prospection should be also archeologically verified, at least partially.

A brief summary (tab. 1,2) shows which types of features represent suitable targets for the geophysical methods and which methods can be employed to get the best results at Early Medieval hillforts. There are two basic issues to consider. First, research of fortifications and related structures. Second, research of the habitation of fortified complexes and their immediate surroundings. Both these issues can be at least partially solved by the use of various methods of geophysical prospection. In research of fortified sections of hillforts, ERT methods and the GPR appear to be most useful. If a fortification was destroyed by fire, the use of magnetic prospection is most appropriate (tab. 1). 
Table 1. Use of individual geophysical methods in research of Early Medieval fortifications. $:-$ - method is often successful, $:-$ - method is successful depending on conditions, $:-$ method is not suitable

\begin{tabular}{|c|c|c|c|c|c|}
\hline Feature/method & Magnetometry & ERT & DEMP & GPR & Gravimetry \\
\hline wood-earth fortification structure, non-burnt & $\bigodot$ & $\ominus$ & $\bigodot$ & $\bigodot$ & $\ddot{\theta}$ \\
\hline wood-earth fortification structure, burnt & $(-)$ & $\bigodot$ & 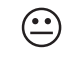 & $\ominus$ & $\ddot{\theta}$ \\
\hline stone fortification elements & $\bigodot$ & $(-)$ & 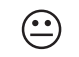 & $(-)$ & $\ominus$ \\
\hline ditch & $(-)$ & $(-)$ & $\ominus$ & $(-)$ & $\ddot{\theta}$ \\
\hline palisade ditch & $(-)$ & $\ddot{\theta}$ & $\ddot{\theta}$ & $\bigodot$ & $\ddot{\theta}$ \\
\hline entrance gate & $(-)$ & $\ominus$ & 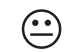 & $\bigodot$ & $\ddot{\theta}$ \\
\hline destruction layer & 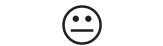 & $(-)$ & $\bigodot$ & (ت) & $\bigodot$ \\
\hline
\end{tabular}

Table 2. Use of individual geophysical methods in the detection of structures which can be expected at Early Medieval hillforts. :-) - method is often successful, $\odot$ - method is successful depending on conditions, $:-$ - method is not suitable

\begin{tabular}{|c|c|c|c|c|c|}
\hline Feature/method & Magnetometry & ERT & DEMP & GPR & Gravimetry \\
\hline sunken dwelling with hearth & ;) & $\odot$ & $\ominus$ & $\odot$ & $\because$ \\
\hline sunken dwelling without hearth & (:) & $\odot$ & 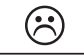 & $\odot$ & 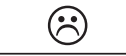 \\
\hline oven, hearth & ; & (:) & (:) & $\odot$ & $\because$ \\
\hline settlement pits & (:) & $\ddot{\theta}$ & $\because$ & $\odot$ & $\because$ \\
\hline ditch & ; & 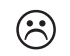 & $\because$ & $\odot$ & $\because$ \\
\hline post hole & $\odot$ & $\because$ & $\because$ & $\odot$ & $\because$ \\
\hline skeletal burial & $\odot$ & $\ddot{\theta}$ & : & $\odot$ & 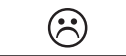 \\
\hline well & ;) & (:) & $\odot$ & $\odot$ & $\because$ \\
\hline unpaved communication & $\odot$ & $\odot$ & : & $\odot$ & $\because$ \\
\hline settlement layer & ; & $\odot$ & $\odot$ & (;) & $\because$ \\
\hline stone architecture & $\odot$ & (:) & ; & (:) & $\odot$ \\
\hline
\end{tabular}

When researching settlement structures at hillforts and their surroundings, we are fully dependent on terrain conditions. Ideal conditions for prospection activities can be found in areas used today as fields and meadows. Nonetheless, modern geophysical equipment also enables to work effectively in hilly and forested environments. The main prerequisite for successful geophysical survey is, first and 
foremost, a well-preserved site undisturbed by more recent factors. In inhabited areas and areas distinctly transformed by modern human activity, chances of positive results of geophysical prospection are small. In common archaeological contexts, however, geophysical survey appears ideal for addressing issues of the size, habitation density and types of features at hillforts. Magnetic prospection is positively of best possibility. The other methods are employed less often and are slightly less appropriate (tab. 2).

In general, looking back at the development and progressive application of geophysical methods into archaeological research of Early Medieval hillforts, there is an obvious shift in the quality of acquired results. It can be therefore expected that in the future the number of geophysical surveys will increase, of both surveys employed in archaeological excavations and independently, in dealing with the issues of hillforts, and not only from the Early Middle Ages.

\section{References}

Bialeková D., 1978, Výskum a rekonštrukcia fortifikácie na slovanskom hradisku v Pobedime, Slovenská Archeológia 26, p. 149-177.

Bialeková D., 1996, Der slawische Burgwall von Pobedim (Ein Beitrag zur Lösung chronologischer und gesellschaftlich-historischer Fragen), [in:] Frühmittelalterliche Machtzentren in Mitteleuropa. Mehrjährige Grabungen und ihre Auswertung. Symposion Mikulčice, 5.-9. September 1994, Internationale Tagungen in Mikulčice 3, eds. Č. Staňa, L. Poláček, Brno, p. 141-147.

Bialeková D., 1998, Zur Bautechnik der Befestigungsmauer des Burgwalls in Pobedim, Bez. Trenčín, [in:] Frühmittelalterlicher Burgenbau in Mittel- und Osteuropa. Tagung Nitra vom 7. bis 10. Oktober 1996, eds. J. Henning, A. Ruttkay, Bonn, p. 383-390.

Dostál B., 1975, Břeclav-Pohansko IV. Velkomoravský velmožský dvorec, Brno.

Dostál B., Hašek V., Měřínský Z., Vignatiová J., 1981, Uplatněni geofyziky při archeologickém výzkumu opevněných sídlišt’ na Moravě, Vlastivědný věstník Moravský 33 , p. 49-59.

Dresler P., 2011, Opevnění Pohanska u Břeclavi, Dissertationes archaeologicae Brunenses/ Pragensesque 11, Brno.

Dresler P., Macháček J., Milo P., Stratjel F., 2013, LLS jako součást komplexní archeologické prospekce v zázemí raně středověkého centra na Pohansku u Břeclavi, [in:] Archeologie a letecké laserové skenováni krajiny/Archaeology and airborne laser scanning of the landscape, eds. M. Gojda, J. John. Plzeň, p. 111-126.

Dresler P., Milo P., Šešulka V., 2007, Magnetic prospection of the rampart of the early medieval hill-fort Pohansko by Břeclav, Czech republic, [in:] $7^{\text {th }}$ International Conference on Archaeological Prospection, Študijné zvesti Archeologického ústavu SAV, vol. 41, no. 1, p. 142-144. 
Fottová E., Henning J., Ruttkay M., 2007, Archeologický výskum včasnostredovekého hradiska v Majcichove. Archäologische Grabung eines frühmittelaltrelichen Burgwalls in Majcichov, [in:] Hospodárske a politické centrum Nitrianskeho kniežatstva. Wirtschaftliches und politisches Zentrum Nitraer Fürstentums, Archaeologia Slovaca Monographiae, Studia 9, eds. K. Pieta, A. Ruttkay, M. Ruttkay, Bojná, Nitra, p. 217-236.

Gajdoš V., 1978, Výsledky geoyzikálneho prieskumu na niektorých archeologických lokalitách na Slovensku, [in:] Geofyzikální prospekce v archeologii. 2. celoštátny seminár archeogeofyziky, Nové Vozokany 1976, Zprávy ČSSA 19, 1977, p. 115-117.

Hašek, V., Měŕnský Z., 1991, Geofyzikální metody v archeologii na Moravě, Brno.

Hašek V., Měřínský Z., Unger J., Vignatiová J., 1983, Výsledky geofyziky v archeologickém výzkumu a průzkumu na Moravě v letech 1979-1982 a jejich metodický př́nos, [in:] Geofyzika a archeologie. 4. celostátní symposium, Dỉm vědeckých pracovník Č SAV Liblice, 1.-4. listopadu 1982, Praha, p. 141-153.

Henning, J., Milo P., 2005, Geofyzikálne prieskumy na rôznych typoch včasnostredovekých lokalit: sídlisko, hradisko, pohrebisko, [in:] Ve službách archeologie 6, Brno, p. 139-150.

Kalousek F., 1971, Břeclav-Pohansko I. Velkomoravské pohřebiště u kostela, Brno.

Kováčová L., Kovár B., Milo P., 2015, Hradisko Pružina-Mesciská a jeho okolie (Hillfort Pružina-Mesciská and its vicinity), [in:] Hradiská - Svedkovia dávnych čias. Zbornik odborných prispevkov o hradiskách a ich obyvateloch, eds. P. Jencík, V. Struhár, Dolná Mariková, p. 175-185.

Křivánek R., 2005, Geofyzikální měrení na Pohansku u Břeclavi v letech 2000-2002, Archeologické rozhledy 57, p. 139-146.

Ludikovský K., Hašek V., Obr F., 1978, Geofyzikální výzkum přičného valu na slovanském hradisku v Pobedimi, Slovenská Archeológia 26, p. 185-192.

Macháček J., 2005, Raně středověké Pohansko u Břeclavi: munitio, palatium, nebo emporium moravských panovníků?, Archeologické rozhledy 57, p. 100-138.

Milo P., 2009, Geofyzikálny prieskum včasnostredovekých sídlisk. Prínos pre archeológiu alebo strata času?, [in:] Archeologie doby hradištní v České a Slovenské republice, Brno, p. 38-54.

Milo P., 2014, Frühmittelalterliche Siedlungen in Mitteleuropa. Eine vergleichende Strukturanalyse durch Archäologie und Geophysik, Studien zur Archäologie Europas 21, Bonn.

Milo P., Dresler P., Macháček J., 2011, Geophysical prospection at the Břeclav-Pohansko stronghold, [in:] Frühgeschichtliche Zentralorte in Mitteleuropa. Studien zur Archäologie Europas, Bd. 14, eds. J. Macháček, Š. Ungerman, Bonn, p. 79-88.

Milo P., Murín I., Prišt’áková M., Tencer T., Vágner M., 2019, Non-destructive survey of early medieval ramparts in the Czech Republica and Slovakia, [in:] New global perspectives on archaeological prospection. $13^{\text {th }}$ International Conference on Archaeological Prospection, 28 August-1 September 2019, Sligo-Ireland, ed. J. Bonsall, Sligo, p. 45-46. 
Pieta K., Haruštiak J., Jakubčinová M., Vangl'ová T., 2011, Výskum včasnostredovekého hradiska Bojná I v rokoch 2007 a 2008, [in:] Archeologické výskumy a nálezy na Slovensku v roku 2008, eds. I. Cheben, K. Douňová, M. Vojteček, Nitra, p. 205-211.

Poláček A., Hofrichterová L., Müller K., Pavelčík J., Kouřil P., 1983, Geofyzikální výzkum archeologických lokalit na severní Moravě, [in:] Geofyzika a archeologie. 4. celostátní symposium di̊m védeckých pracovníků ČSAV Liblice, 1.-4. listopadu 1982, ed. E. Plesková-Štiková, Praha, p. 159-168.

Procházka R., 2009, Vývoj opevňovaci techniky na Moravě a v českém Slezku v raném středověku, Spisy Archeologického ústavu AVČR Brno, v.v.i. 38. Brno.

Ruttkay M., Henning J., Fottová E., Eyub E., Milo P., Tirpák J., 2006, Archeologický výskum a geofyzikálna prospekcia na včasnostredovekých hradiskách v Majcichove a v Pobedime, [in:] Ve službách archeologie 7, Brno, p. 93-112.

Šolle M., 1977, Zkušenost a výsledky spolupráce př́rodních věd včetně geofyzikálních metod při archeologických výzkumech českých hradišt’ 8.-12. století, [in:] Geofyzikální prospekce v archeologii - 2. celoštátny seminár archeogeofyziky Nové Vozokazy 1976, Zprávy Československé společnosti archeologické 19, sešit 4-5, p. 95-96.

Staňa, Č., 1972, Velkomoravské hradiště Staré Zámky u Líšně, Monumentorum tutela - ochrana pamiatok 8, p. 109-171.

\section{MOŻLIWOŚCI WYKORZYSTANIA METOD GEOFIZYCZNYCH W BADANIACH WCZESNOŚREDNIOWIECZNYCH GRODÓW}

Streszczenie

Słowa kluczowe: grody, wczesne średniowiecze, metody geofizyczne, Morawy, Słowacja.

W artykule przedstawiono wyniki badań wczesnośredniowiecznych grodzisk z północnych regionów środkowego basenu Dunaju, zwłaszcza Moraw oraz zachodniej Słowacji, przy wykorzystaniu metod geofizycznych. Brano pod uwagę przede wszystkim obiekty datowane na IX wiek, które powstały w związku z rozwojem tzw. Wielkich Moraw. Badania geofizyczne wczesnośredniowiecznych grodzisk mają długą historię. W archeologii czechosłowackiej pierwszym, zbadanym w ten sposób obiektem w latach 50. XX wieku było wzgórze Stará Kouřim. Systematyczne pomiary geofizyczne na morawskich grodziskach rozpoczęto pod koniec lat 70. i na początku 80., ubiegłego stulecia; prowadził je Vladimír Hašek (Uherské Hradiště - Staré Město). Nowsze badania morawskich grodów skupiły się na obszarach rozległych kompleksów obronnych - między innymi Mikulčice i Břeclav-Pohansko.

Dzięki odpowiedniemu połączeniu różnych metod geofizycznych jesteśmy w stanie, w odpowiednich warunkach, wykryć niemal wszystkie rodzaje obiektów - budynki, miejsca produkcji, różnego rodzaju elementy konstrukcyjne (w tym części systemów fortyfikacyjnych), a także ślady ognia. Należy jednak podkreślić, że ich zastosowanie nie może zastąpić wykopaliskowych prac archeologicznych, może je jedynie uzupełniać. Wyniki 
badań geofizycznych nie zawsze oddają pełen obraz badanego obszaru oraz dostarczają dokładnych i jasnych informacji, mają swoje ograniczenia. Ostateczne decyzje dotyczące oceny terenu nigdy nie powinny być podejmowane wyłącznie na podstawie geofizyki, a wyniki poszukiwań należy przynajmniej częściowo zweryfikować archeologicznie.

Podstawowymi materiałami budowlanymi używanymi do wznoszenia wczesnośredniowiecznych fortyfikacji były ziemia i drewno, w niektórych przypadkach uzupełnione kamieniami. W początkowej fazie rozwoju tych technik na terytorium Centralnego Basenu Dunajskiego dominowały proste konstrukcje charakteryzujące się luźno ułożonymi drewnianymi słupami połączonymi wiklinowymi ścianami. Typowe elementy fortyfikacyjne tego okresu składały się z prostych drewnianych palisad. W połowie IX wieku zastąpiono je bardziej złożonymi fortyfikacjami kamienno-drewnianymi.

Główne zadania w zakresie badań geofizycznych często polegają na wykrywaniu form niewidocznych lub słabo dostrzegalnych w terenie, które mogą wskazywać na obecność elementów fortyfikacyjnych, takich jak rowy, wały lub palisady. Wykorzystanie tych badań pozwala odpowiedzieć na istotne pytania dotyczące form, budowy, objętości lub głębokości zalegania tych elementów. Ważną kwestią, którą ujawniają jest również stan zachowania fortyfikacji, co jest kluczowe w planowaniu prac archeologicznych.

Podstawowym warunkiem przeprowadzenia udanych badań geofizycznych jest przede wszystkim dobrze zachowane miejsce, współcześnie niezakłócone. Na obszarach zamieszkałych i silnie przekształconych w wyniku działalności człowieka, szanse na uzyskanie pozytywnych wyników poszukiwań geofizycznych są niewielkie. Jednak wykorzystanie badań geofizycznych wydaje się idealnym sposobem rozwiązywania ważnych problemów dotyczących grodzisk. Biorąc zatem pod uwagę rozwój i coraz większe zaangażowanie metod geofizycznych w badaniach archeologicznych widać obecnie wyraźnie zmianę jakości uzyskiwanych wyników. Można spodziewać się, że w przyszłości wzrośnie liczba i znaczenie badań geofizycznych, zarówno prowadzonych w ramach prac wykopaliskowych, jak i niezależnie od nich, w rozpoznaniu problematyki między innymi wczesnośredniowiecznych grodzisk. 